\title{
Determination of Folic Acid by Ultra-High Performance Liquid Chromatography in Certain Malt-based Beverages after Solid-Phase Extraction
}

\author{
Elif Mine Öncü-Kaya* \\ Department of Chemistry, Faculty of Science, Anadolu University, 26470 Eskişehir, Turkey \\ Tel.: +90 222 3350580-ext. 4779; fax: +90 2223204910 . \\ emoncu@anadolu.edu.tr \\ *Correspondence author
}

Received: 13 December 2016

Accepted: 29 June 2017

DOI: 10.18466/cbayarfbe.339315

\begin{abstract}
The aim of the present work was to develop and validate an efficient Ultra-High Performance Liquid Chromatography (UHPLC) method for the determination of folic acid (FA) in malt-based beverages. Solidphase extraction (SPE) procedure was used for cleanup and preconcentration of the malt-based beverages before the UHPLC analysis. The analysis was performed in a C18 column (2.1x50 mmx1.8 $\mu \mathrm{m})$ using a solvent system of ACN: $0.1 \%$ formic acid in water $(10: 90, \mathrm{v} / \mathrm{v})$ by isocratic elution. Injection volume was $5 \mu \mathrm{L}$. The flow rates of the mobile phase were maintained at $0.2 \mathrm{~mL} \mathrm{~min}^{-1}$ for $0.00-4.00 \mathrm{~min}$ and $0.5 \mathrm{~mL}$ $\mathrm{min}^{-1}$ for 4.01-12.00 min. Methyl paraben was used as the internal standard (IS). The FA and IS signals were detected at $284 \mathrm{~nm}$ and $254 \mathrm{~nm}$, respectively. Under these conditions, FA and IS were separated in $3.6 \mathrm{~min}$ and $11.4 \mathrm{~min}$, respectively. The method was successfully validated in terms of precision, accuracy, linearity, limits of detection (LOD) and quantification (LOQ) parameters. The relative standard deviations for intra- and inter-day precision were less than $1.5 \%$. Good linearity with a high correlation coefficient was achieved over the concentration range of $20.13 \mu \mathrm{g} \mathrm{L}^{-1}-2004 \mu \mathrm{g} \mathrm{mL} \mathrm{m}^{-1}$ for FA. The LOD and LOQ values were $6.66 \mu \mathrm{g} \mathrm{L}^{-1}$ and $20.13 \mu \mathrm{g} \mathrm{L}^{-1}$, respectively. Good recovery values were found ranged between 99.1\% and $106 \%$ for boza and vitamin fortified malt drink. The proposed method was successfully applied for the determination of FA in malt beers, vitamin fortified malt drinks and boza samples.
\end{abstract}

Keywords: Boza, Folic acid, Malt-based beverages, Method development, UHPLC, Validation.

\section{Introduction}

Folic acid (FA) stands out as a molecule having biological importance in recent years. The name folate usually outlines a class of compounds with chemical structures related to pteroylmonoglutamic acid and generally recognised as folic acid (FA, vitamin M, B9 or B11) [1, 2]. There are more than 100 compounds that can be defined as folates [3] and folic acid is the simplest synthetic and oxidised form of folates [4]. Folate is present in legumes, egg, kidney, liver, tongue, citrus fruits, leafy green vegetables, beans, wheat germ, and yeast $[1,5-8]$.

Folate is synthesized solely by microorganisms and plants so that humans need to intake the vitamin from different dietary sources as a natural form or from supplements and enriched foods as a folic acid [5, 6]. Since FA is more stable, cheap and easily absorbable synthetic form and it reveals higher bioavailability than naturally occurring food folate, this water soluble B group vitamin is increasingly utilized for food fortification purposes [9]. The recommend daily intakes (RDI) for folate change from 150 to $600 \mu \mathrm{g}$ per day depending on the age and sex of the individuals and also vary notably from country to country [8]. The United States Public Health Service suggests that all women of childbearing age should use $400 \mu \mathrm{g}$ daily dose of folic acid for the prevention of spina bifida or other neural tube defects [10]. Currently, some European countries recommend that intake $500 \mu \mathrm{g}$ of daily folic acid for women who are breastfeeding [8].

When FA is converted into folates in the body, it acts an important role in various biochemical pathways including the synthesis of red blood cells, amino acid metabolism such as methionine and homocysteine, nucleotide synthesis and formation of RNA and DNA, DNA replication, repair and methylation, development of tissues and the brain of the foetus and the growth of a baby [1, 8, 11, 12]. FA deficiency has been related to some critical diseases for instance gigantocytic anemia and leukopenia, devolution of mentality, Alzheimer's 
disease, psychosis, neural tube defects (NTDs), certain forms of cancer such as pancreatic, colorectal and breast cancers $[8,11,13,14]$. Furthermore, blood homocysteine concentration increases due to the inadequate intake of FA which may lead to coronary heart disease and stroke [14]. Briefly the vitamin is vital for humans for growth, reproduction and continue of normal body function and so that FA shows a critical role in the human nutrition [12].

When the increasing significance of folates in health or disease take into consideration, quantitative analyses of FA in foods is very important [15]. Therefore, analysis of FA with a reliable analytical method is very important. For this purpose numerous analytical methods have been used in the literature such as microbiological assay [16], immunoassay [17], UV spectrophotometric [18], highperformance liquid chromatography (HPLC) [9, 19, 20, 21], liquid chromatography-mass spectrometry (LC-MS) [22], capillary electrophoresis (CE) [3, 5, 9, 13], ultrahigh performance liquid chromatography (UHPLC) [1] and UHPLC-MS [23].

The microbiological assay is usually used as a standard method for determination of food folates. Although it has high sensitivity, this method cannot separate the various forms of folate. Furthermore, the experimental method is time-consuming and tedious. On the other hand, HPLC is more accurate, easy and can determine individual folate forms when compared to this method $[17,19]$. Although LC-MS provide many advantages, this instrument is quite expensive and necessitate expertise of the analyst [24]. Among these techniques, HPLC is commonly used for FA analysis in different food matrices with various separation columns, mobile phases, and detectors however there is still need for the optimisation and development of novel analytical methods [15].

The Ultra-high performance liquid chromatography (UHPLC) has emerged as a powerful method widely used nowadays due to using new technologies small (sub-2$\mu \mathrm{m})$ particle size packed columns with small diameter. UHPLC has recently been started popular in various analyses because it has significant advantages than the HPLC technique such as its higher speed and efficiency, less time and solvent consumption criteria by keeping the equivalent separation power [25-27]. Furthermore, analytes can be detected at very low concentrations by the UHPLC system due to improved signal-to-noise ratio [28].

There are some standard official methods which are based on microbiological assay to measure total folates in vitamin preparations [29] and in certain foods such as fortified infant formula [30], cereals [31], and for foodstuffs [32, 33]. However there are no standard methods enacted yet for folates in foods with chromatographic methods. Because folate determinations show large differences for various foods with high relative standard deviation (RSD) values [24, 33]. So that possibility of matrix specific problems must be get through for different samples from the investigators [15].

Malt beverages, which are fermented drinks, are commonly known as the healthy drinks. Moreover these drinks are FA source for pregnant population and also are believed to help increase milk production during the lactation. Since the breast milk is a source of folic acid for the breastfed infant, malt beverages including alcohol free vitamin fortified malt drink and boza are selected for investigation of folic acid in this research [34]. Boza is a Turkish traditional malt beverage which is made from millet, maize, wheat or rice and their flours by fermentation. The highly viscous beverage consumed especially in winter is quite nutritious due to its vitamin content, lactic acid, protein, fibre and carbohydrate [35, 36].

The objective of present study is to investigate the FA level in certain malt-based beverages (malt beers, boza and vitamin fortified malt drinks) by a reliable UHPLC method. To the best of author's knowledge there are limited study about malt beverages by UHPLC method and also there is no report in the literature about FA analysis in boza by the method. In this study a simple, sensitive and efficient UHPLC method was developed and validated for the determination of FA in malt-based beverages which are consumed in Turkey.

\section{Experimental}

\subsection{Chemicals and Materials}

Folic acid (FA), methyl paraben (IS), sodium acetate ( $\geq 99.0 \%$ ), sodium L-ascorbate (99.0\%), acetonitrile, methanol, formic acid and sodium phosphate dibasic dihydrate $(\geq 98.5 \%)$ were provided from Sigma (St. Louis, MO, USA). Glacial acetic acid (99.5\%) was purchased from Carlo Erba (Milan, Italy). Orthophosphoric acid (Puriss 85.0\%) was obtained from Riedel-de Haen (Seelze, Germany). Supelclean 500 mg LC-18 SPE cartridges (Supelco, Beilefonte, PA, USA) were utilized for solid phase extraction (SPE). Analytical reagent grade chemicals were used in all the experiments. All of the malt beverages samples (malt beers, boza and vitamin fortified malt drink) were purchased from markets in Eskişehir (Turkey) and were analysed on the same day.

The ultra-pure deionized water was purified by the Millipore, Synergy Water Purification System (Rotterdam, Netherland). All the solutions were degassed with a Sonorex ultrasonic bath (Bandelin, Berlin, Germany). The samples were dissolved and mixed by a Vortex (2G 560-E, Daigger Scientific Industries, Bohemia, USA). SevenCompact pH/Ion meter (Mettler Toledo, Columbus, Ohio, USA) was utilized for 
measuring the $\mathrm{pH}$ of solutions. Evaporation procedures were achieved by using a rotary evaporator (Rotavapor R-200, heating Bath B-490, Buchi, Flawil, Switzerland).

\subsection{Preparation of Standard Solutions}

Standard stock solution of folic acid was prepared in 0.1 $\mathrm{M}$ phosphate buffer (pH 7.0) containing 1.0\% (w/v) sodium ascorbate at a concentration of $2.27 \times 10^{-3} \mathrm{M}$ [37]. The $\mathrm{pH}$ of the solution was adjusted by orthophosphoric acid. The stock FA solution further diluted with $0.01 \mathrm{M}$ acetate ( $\mathrm{pH} 4.9$ ) for preparation of $2.27 \times 10^{-5} \mathrm{M}$ and $6.81 \times 10^{-6} \mathrm{M}$ FA solutions. $6.81 \times 10^{-6} \mathrm{M}$ of FA solution used for the preparation of calibration standard solutions. The appropriate amount of methyl paraben (IS) was weighed for preparation of $7.62 \times 10^{-3} \mathrm{M}$ stock solution in methanol. Then $4.57 \times 10^{-5} \mathrm{M}$ of IS was prepared from this solution by diluting with water and was used further experiments. All the calibration standard solutions were prepared immediately before use by dilution with water. A $20 \mathrm{mM}$ sodium acetate buffer was prepared by dissolving sodium acetate in water and $\mathrm{pH}$ of the solution was adjusted to 4.0 by using acetic acid. Stock solutions were divided to aliquots and stored in the $-20 \circ \mathrm{C}$. All working standard solutions were stored in the dark at 4 ${ }^{\circ} \mathrm{C}$.

\subsection{UHPLC Equipment and Conditions}

An Agilent 1290 Infinity UHPLC system (Waldbronn, Germany) equipped with a UV detector was used in this study. An Eclipse Plus RRHD C18 column (2.1x50 mmx1.8 $\mu \mathrm{m})$ and guard column (2.1x5 mmx1.8 $\mu \mathrm{m})$ from Agilent (Waldbronn, Germany) were utilized in the UHPLC analyses. The isocratic elution was used and the mobile phase consisted of $10 \%$ acetonitrile and $90 \%$ water with $0.1 \%$ formic acid. The flow rates of the mobile phase were maintained at $0.2 \mathrm{~mL} \mathrm{~min}^{-1}$ for $0-4 \mathrm{~min}$ and $0.5 \mathrm{~mL} \mathrm{~min}^{-1}$ for $4.01-12 \mathrm{~min}$. The signals were detected at $284 \mathrm{~nm}$ within the ten minute and the wavelength was changed to $254 \mathrm{~nm}$ at ten minute. 284 $\mathrm{nm}$ and $254 \mathrm{~nm}$ are the maximum absorbance wavelengths of FA and IS, respectively. Injection volume was $5 \mu \mathrm{L}$. Methyl paraben was used as an internal standard (IS). The UHPLC column was kept at $25{ }^{\circ} \mathrm{C}$ temperature. Oto sampler was cooled to $10{ }^{\circ} \mathrm{C}$ during the experiments.

\subsection{Sample Preparation}

2.4.1 Preparation of Samples to Solid-Phase Extraction (SPE)

Firstly all of the gases in the beer samples were removed by using ultrasonic bath for a while. $100 \%$ malt beer, vitamin fortified malt beverage and boza samples were filtered from $0.45 \mu \mathrm{m}$ syringe filter prior to SPE procedure. Boza samples are considerably viscous than the malt beverages so that they require different sample pre-treatment explained as following. Approximately 25-30 g boza sample was weighed and it was centrifuged for $30 \mathrm{~min}$ at $27,216 \mathrm{xg}$. $10 \mathrm{~mL}$ of supernatant was transferred to a tube and $20 \mathrm{~mL}$ of acetonitrile was added for the precipitation of its proteins. And then clear phase was evaporated to dryness with rotavapor [38]. Residue was dissolved in $10 \mathrm{~mL}$ of water, filtered from $0.45 \mu \mathrm{m}$ and then passed through the SPE column.

\subsubsection{Solid-Phase Extraction (SPE) Procedure}

The SPE process was succeeded by a previous method that reported elsewhere [39]. Firstly, C18 SPE column was conditioned by washing with methanol $(5 \mathrm{~mL})$, and water $(10 \mathrm{~mL})$ without allowing the cartridge to dry out. $10 \mathrm{~mL}$ of malt beverage sample was passed from the cartridge. Then, folic acid was eluted through $3 \mathrm{~mL}$ of methanol:sodium acetate buffer (20 mM, pH 4) (50:50, $\mathrm{v} / \mathrm{v}$ ) and this solution was homogenised with vortex agitation. $0.5 \mathrm{~mL}$ of methyl paraben (IS) $\left(4.57 \times 10^{-5} \mathrm{M}\right)$ was added to the $1.0 \mathrm{~mL}$ of the eluate and the volume was then completed to $4 \mathrm{~mL}$ by methanol:sodium acetate buffer (20 mM, pH 4). Other dilutions of the samples are also adjusted to as $1: 8(\mathrm{~V}: \mathrm{V}$, IS:Total solution) ratio. After mixing, the sample solution was injected to the UHPLC column.

\subsection{Statistics}

GraphPad Prism 6.0 software (GraphPad Software, San Diego, CA) was used for the statistical analyses of the experimental data.

\section{Results and Discussion \\ 3.1 Optimisation of UHPLC Method}

The ideal chromatographic conditions were optimised by using parameters including flow rate, injection volume, mobile phase composition and detection wavelength for FA along with IS. Different mobile phase systems of isocratic or gradient elution and different proportions of acetonitrile and $0.1 \%$ formic acid in water were tried for determine to best chromatographic conditions. Thus FA and IS were successfully separated from other peaks in food matrices. However it was probable to obtain the peaks in a shorter time but a poor resolution was seen when the samples were analysed. Methyl paraben was a most suitable compound as an IS for malt beverages analyses with the UHPLC system. Final concentration of IS was used as $5.71 \times 10^{-6} \mathrm{M}$ at all of experiments. Folic acid and IS were separated in nearly $3.6 \mathrm{~min}$ and 11.4 min, respectively in the optimum UHPLC conditions (Figure 1) which was mentioned in the 'Experimental Section 2.3'.

The compounds are found at quite low concentration levels in food samples so that a preconcentration and clean-up step is necessary [26]. SPE not only provides preconcentration of analyte species but also separates matrix components which are potential interfering. Accordingly SPE method was used for this purpose in this study. Since the extraction procedure was a very important step for FA determination, various SPE methods by using strong anion exchange (SAX) and 
reverse phase C18 SPE columns were tried for the extraction of FA from malt beverages. Besides different solutions were also tested to get optimum extraction conditions for C18 SPE column. The best performance was achieved with C18 SPE column and the SPE procedure was given in the 'Experimental Section 2.4.2'

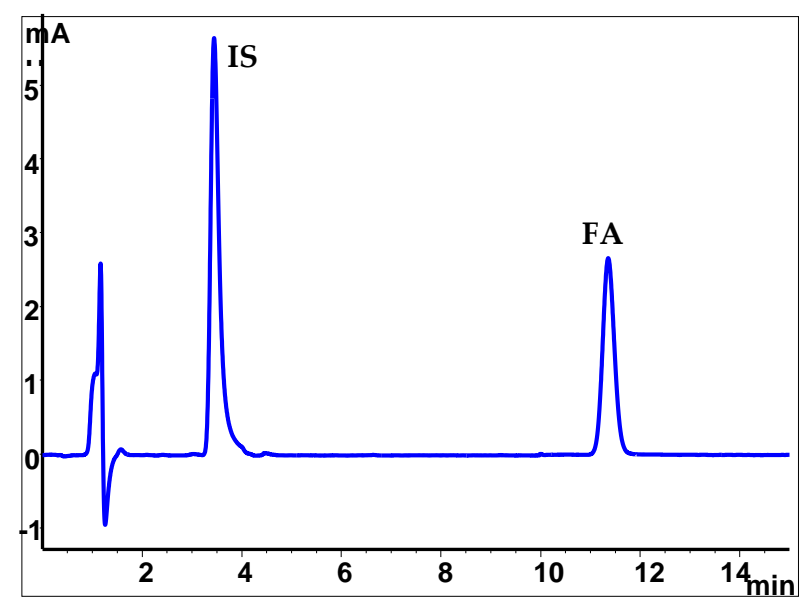

Figure 1. Typical UHPLC chromatogram of standard FA $\left(2.27 \times 10^{-6} \mathrm{M}\right)$ and IS $\left(5.71 \times 10^{-6} \mathrm{M}\right)$ in optimum conditions

\subsection{Validation of the UHPLC Method}

The International Conference on Harmonization (ICH) of Technical Requirements (CPMP/ICH/281/95) guidelines was performed for the validation of the method with following validation parameters: precision, linearity, accuracy, limit of detection (LOD), and limit of quantification (LOQ) [40].

\subsubsection{Precision}

The precision of the method was assessed by intra-day and inter-day repeatability for three different concentrations of FA. For this purpose $9.08 \times 10^{-7} \mathrm{M}$, $2.27 \times 10^{-6} \mathrm{M}$ and $4.54 \times 10^{-6} \mathrm{M}$ of FA solutions with fixed amount of $5.71 \times 10^{-6} \mathrm{M}$ IS were used in the repeatability study. These were injected six times for three different days. The peak normalization (PN) values were calculated by dividing the area values by their retention times. After, the rate of peak normalizations (PN) were obtained by dividing those of PN values of FA to IS. The intra-day ( $n=6$ each) and inter-day $(n=18)$ results of rates of peak normalization and their statistical parameters are presented in Table 1 . The RSD\% values change between $0.20-0.69$ (intra-day) and 0.52-1.37 (inter-day), and these results express that the method is highly repeatable.
Table 1. The results of repeatability obtained from determination of FA using ratios of peak-normalization values ( $\mathrm{R}=$ PNFA/PNIS)

\begin{tabular}{|c|c|c|c|c|}
\hline \multirow{2}{*}{$\begin{array}{c}9.08 \times 10^{-7} \mathrm{M} \\
\text { FA }\end{array}$} & \multicolumn{3}{|c|}{$\begin{array}{l}\text { Intra-day results } \\
\quad(n=6 \text { each) }\end{array}$} & \multirow{2}{*}{$\begin{array}{c}\text { Inter- } \\
\text { day } \\
\text { results } \\
(n=18)\end{array}$} \\
\hline & $\begin{array}{l}\text { First } \\
\text { Day }\end{array}$ & $\begin{array}{l}\text { Second } \\
\text { Day }\end{array}$ & $\begin{array}{l}\text { Third } \\
\text { Day }\end{array}$ & \\
\hline $\bar{X}$ & 1.99 & 1.98 & 2.00 & 1.99 \\
\hline SD & 0.01 & 0.01 & 0.01 & 0.01 \\
\hline RSD\% & 0.69 & 0.45 & 0.25 & 0.52 \\
\hline \multirow{2}{*}{$\begin{array}{c}2.27 \times 10^{-6} \mathrm{M} \\
\text { FA }\end{array}$} & \multicolumn{3}{|c|}{$\begin{array}{l}\text { Intra-day results } \\
\quad(n=6 \text { each })\end{array}$} & \multirow{2}{*}{$\begin{array}{c}\text { Inter- } \\
\text { day } \\
\text { results } \\
(n=18)\end{array}$} \\
\hline & $\begin{array}{l}\text { First } \\
\text { Day }\end{array}$ & $\begin{array}{l}\text { Second } \\
\text { Day }\end{array}$ & $\begin{array}{l}\text { Third } \\
\text { Day }\end{array}$ & \\
\hline $\bar{X}$ & 4.96 & 5.00 & 4.89 & 4.95 \\
\hline SD & 0.01 & 0.01 & 0.02 & 0.05 \\
\hline RSD\% & 0.23 & 0.21 & 0.31 & 1.00 \\
\hline \multirow{2}{*}{$\begin{array}{c}4.54 \times 10^{-6} \mathrm{M} \\
\text { FA }\end{array}$} & \multicolumn{3}{|c|}{$\begin{array}{c}\text { Intra-day results } \\
(n=6 \text { each })\end{array}$} & \multirow{2}{*}{$\begin{array}{c}\text { Inter- } \\
\text { day } \\
\text { results } \\
(n=18)\end{array}$} \\
\hline & $\begin{array}{l}\text { First } \\
\text { Day }\end{array}$ & $\begin{array}{l}\text { Second } \\
\text { Day }\end{array}$ & $\begin{array}{l}\text { Third } \\
\text { Day }\end{array}$ & \\
\hline $\bar{X}$ & 8.62 & 8.38 & 8.61 & 8.53 \\
\hline SD & 0.02 & 0.03 & 0.02 & 0.12 \\
\hline RSD\% & 0.20 & 0.40 & 0.20 & 1.37 \\
\hline
\end{tabular}

$\bar{X}$ : mean; SD: standard deviation; RSD\%: percent of relative standard deviation; CL: confidence limit for the 95\% probability level

\subsubsection{Linearity and Sensitivity}

Calibration curve was found (concentrations against RPN values) by preparing six different concentrations of the standard FA solutions with fixed amount of $5.71 \times 10^{-6} \mathrm{M}$ IS as seven replicates. The method is linear in the calibration range of $20.13 \mu \mathrm{g} \mathrm{L}^{-1}\left(1.51 \times 10^{-8} \mathrm{M}\right)-2004$ $\mu \mathrm{g} \mathrm{L}^{-1}\left(4.54 \times 10^{-6} \mathrm{M}\right)$ of FA with a high correlation coefficient $\left(r^{2}=0.9998\right)$ and the intercept of the curve is not considerably different from zero. The LOD and LOQ values are $6.66 \mu \mathrm{g} \mathrm{L}^{-1}$ and $20.13 \mu \mathrm{g} \mathrm{L}^{-1}$, respectively. Results are summarised in Table 2.

Table 2. Calibration results of FA with their statistical analysis under the optimum UHPLC conditions $(n=7)$

\begin{tabular}{|l|c|}
\hline Linearity range $\left(\boldsymbol{\mu g ~ \mathbf { ~ L } ^ { - 1 }}\right)$ & $20.13-2004$ \\
\hline Slope \pm SD & $(24360 \pm 51.37) \times 10^{2}$ \\
\hline Intercept \pm SD & $-0.0649 \pm 0.0111$ \\
\hline $\mathbf{r}^{2}$ & 0.9998 \\
\hline Sy,x & 0.0514 \\
\hline $\mathbf{L O D}\left(\boldsymbol{\mu g ^ { - 1 }}\right)$ & 6.66 \\
\hline $\mathbf{L O Q}\left(\boldsymbol{\mu \mathbf { g ~ L } ^ { - 1 }}\right)$ & 20.13 \\
\hline
\end{tabular}

r: correlation coefficient; Sy,x : standard deviation of calibration equation; LOD: limit of detection; LOQ: limit of quantification; $n$ : number of experiments 


\subsubsection{Accuracy}

Accuracy was tested by means of recovery. Boza and vitamin fortified malt drink samples containing known amounts of folic acid were spiked with three addition levels of standard folic acid for determination of recovery. For this purpose, boza samples spiked with $4.54 \times 10^{-7}, 9.08 \times 10^{-7}$ and $2.27 \times 10^{-6} \mathrm{M}$ of folic acid and vitamin fortified malt drink samples spiked with $9.08 \times 10^{-7}, 2.27 \times 10^{-6}$ and $4.54 \times 10^{-6} \mathrm{M}$ of folic acid were used in the recovery experiments. This spiking procedure was repeated twice for all concentrations. Two unspiked samples for each boza and vitamin fortified malt drink were also used in this experiments. Three measurements were achieved for each level of addition. As seen in Table 3 , good recovery values were found ranged between $97.8 \%$ and $106 \%$ for boza and vitamin fortified malt drink. These recovery values are acceptable for quantification of FA in boza and malt-based beverages.

\subsubsection{Stability}

The stability of the various folates changes and depends on oxidants, $\mathrm{pH}$ and catalysts, even the type of buffer ions effect the vitamers [33]. For this purpose, it was mentioned in Experimental section (2.2), sodium ascorbate was added to increase the stability of the FA solution [37]. Furthermore, FA is sensitive to degradation by heat, oxidation, and ultraviolet light [41]. Therefore, all of the FA solutions were either freshly prepared or they were kept in a refrigerator in the dark during analysis.

The stability of FA was assessed under different storage conditions at three concentrations $\left(2.83 \times 10^{-7}, 9.08 \times 10^{-7}\right.$ and $2.27 \times 10^{-6} \mathrm{M}$ ). For this purpose, short-term, longterm and refrigerator stabilities of FA were studied. To test short-term stability, solutions were preserved at room temperature for $24 \mathrm{~h}$. The long-term stability was evaluated after storage of FA solutions in a freezer at -20 ${ }^{\circ} \mathrm{C}$ for 24 days. For refrigerator stability, the solutions were stored at $4{ }^{\circ} \mathrm{C}$ for 7 days and then analyzed. The stability results were considered by comparing peak area ratios of the analytes with those of freshly prepared samples. The results are given in Table 4 show that FA display satisfactory stability in aqueous solutions at these conditions except long-term stability. FA was started to deteriorate during storage at $-20^{\circ} \mathrm{C}$ for 24 days (Longterm stability). In refrigerator conditions, FA was stable up to 7 days of storage when the solutions were protected from light.

Table 3. Concentration, recovery, standard and relative standard deviation values of FA in boza and vitamin fortified malt drink samples determined by UHPLC $\left(n=2^{\mathrm{a}} ; \mathrm{l}=3\right)$

\begin{tabular}{|c|c|c|c|}
\hline $\begin{array}{c}\text { Spiked FA } \\
\text { concentration } \\
\text { (M) }\end{array}$ & $\begin{array}{c}\text { Recovery }(\%)^{b} \\
(n=2 ; l=3)\end{array}$ & SD & $\begin{array}{c}\text { RSD } \\
\%\end{array}$ \\
\hline boza & & & \\
\hline $4.54 \times 10^{-7}$ & 104.40 & 5.85 & 5.60 \\
\hline $9.08 \times 10^{-7}$ & 99.12 & 4.68 & 4.72 \\
\hline $2.27 \times 10^{-6}$ & 106.37 & 9.01 & 8.47 \\
\hline $\begin{array}{c}\text { vitamin fortified } \\
\text { malt drink } \\
9.08 \times 10^{-7}\end{array}$ & 99.79 & 3.26 & 3.27 \\
\hline $2.27 \times 10^{-6}$ & 105.62 & 1.54 & 1.45 \\
\hline $4.54 \times 10^{-6}$ & 97.83 & 3.58 & 3.65 \\
\hline
\end{tabular}

${ }^{a} n$ : number of experiments; l: number of injections

${ }^{b}$ Recovery $=[($ spiked sample result - unspiked sample result $) /($ known spiked concentration) $\times 100]$

Table 4. Stability of FA under different conditions $(n=3)$

\begin{tabular}{|c|c|c|c|c|c|c|c|}
\hline \multicolumn{2}{|c|}{$\begin{array}{c}\text { Added FA } \\
\left(\mathrm{mol} \mathrm{L}^{-1}\right)\end{array}$} & \multicolumn{2}{|c|}{$\begin{array}{c}\text { Short-term stability } \\
\text { (24 h, room temperature) }\end{array}$} & \multicolumn{2}{|c|}{$\begin{array}{l}\text { Long-term stability } \\
(24 \text { days, }-20 \circ \mathrm{C})\end{array}$} & \multicolumn{2}{|c|}{$\begin{array}{c}\text { Refrigerator stability } \\
\text { (7 days) }\end{array}$} \\
\hline & & $\begin{array}{c}\text { Remained } \\
(\%) \\
(\text { mean } \pm \text { SD) }\end{array}$ & $\begin{array}{l}\text { RSD } \\
(\%)\end{array}$ & $\begin{array}{c}\text { Remained } \\
(\%) \\
(\text { mean } \pm \text { SD) }\end{array}$ & $\begin{array}{l}\text { RSD } \\
(\%)\end{array}$ & $\begin{array}{c}\text { Remained } \\
(\%) \\
(\text { mean } \pm \text { SD) }\end{array}$ & $\begin{array}{l}\text { RSD } \\
(\%)\end{array}$ \\
\hline \multirow{3}{*}{ FA } & $2.83 \times 10^{-7}$ & $103.36 \pm 13.52$ & 13.07 & $104.05 \pm 0.77$ & 0.74 & $91.76 \pm 3.82$ & 4.17 \\
\hline & $9.08 \times 10^{-7}$ & $107.02 \pm 2.60$ & 2.43 & $150.78 \pm 3.48$ & 2.31 & $94.93 \pm 2.44$ & 2.57 \\
\hline & $2.27 \times 10^{-6}$ & $114.98 \pm 0.54$ & 0.47 & $121.64 \pm 0.91$ & 1.37 & $96.78 \pm 0.84$ & 0.75 \\
\hline
\end{tabular}

Remained \% = (peak normalisation of FA after the mentioned storage conditions/peak normalisation of fresh FA) $\times 100$

\subsubsection{Robustness}

The robustness of the proposed method was studied by doing deliberate alterations in flow rate of mobile phase, column temperature, composition of mobile phase and detector wavelength. Parameters regarding robustness are given in Table 5. The RSD\% values are smaller than 6.0 and it can be considered that the method is highly robust.
Table 5. The results of robustness of FA $(n=3)$

\begin{tabular}{|l|c|c|}
\hline \multicolumn{1}{|c|}{ Parameter } & RSD\% & SE \\
\hline $\begin{array}{l}\text { Flow rate of solvent } \\
\left(\mathbf{0 . 1 5} \text { mL } \text { min }^{-1}\right)\end{array}$ & 3.63 & 0.04 \\
\hline $\begin{array}{l}\text { Flow rate of solvent } \\
\left(\mathbf{0 . 3} \text { mL } \text { min }^{-1}\right)\end{array}$ & 2.05 & 0.03 \\
\hline
\end{tabular}




\begin{tabular}{|l|c|c|}
\hline $\begin{array}{l}\text { Column temperature } \\
\left(\mathbf{2 5}{ }^{\circ} \mathbf{C}\right)\end{array}$ & 0.65 & 0.01 \\
\hline $\begin{array}{l}\text { Column temperature } \\
\left(\mathbf{3 0}{ }^{\circ} \mathbf{C}\right)\end{array}$ & 0.26 & 0.01 \\
\hline $\begin{array}{l}\text { The composition of } \\
\text { mobile phase (9\%) }\end{array}$ & 5.97 & 0.05 \\
\hline $\begin{array}{l}\text { The composition of } \\
\text { mobile phase (11\%) }\end{array}$ & 3.14 & 0.06 \\
\hline $\begin{array}{l}\text { Detector wavelength } \\
\text { (280 nm for FA) }\end{array}$ & 5.32 & 0.10 \\
\hline $\begin{array}{l}\text { Detector wavelength } \\
\text { (284 nm for FA) }\end{array}$ & 1.42 & 0.03 \\
\hline
\end{tabular}

$S E$ (standard error of mean $)=\frac{S D}{\sqrt{n}} ; S D$ : standard deviation

\subsection{Application of the UHPLC Method}

The proposed method was applied to 7 samples of maltbased beverages. FA amounts in malt-based beverages were calculated via equation obtained from calibration curve and the results are given in Table 6. As it can be seen from the Table 6 , the contents of FA were found as $36.63-196.80 \mu \mathrm{g} \mathrm{kg}^{-1}$ with good RSD\% values in the mentioned malt beverages. FA was not detected in 2 of the boza samples. A typical chromatograms of boza, vitamin fortified malt beverage and malt beer are shown in Figure 2.

Table 6. Results for the determination of FA in the different food samples $\left(\mu \mathrm{gg}^{-1}\right)(\mathrm{n}=6)$

\begin{tabular}{|l|c|c|c|}
\hline Sample & $\overline{\boldsymbol{X}}$ & SD & RSD\% \\
\hline Sample 1 (Boza) & 36.63 & 1.97 & 5.38 \\
\hline Sample 2 (Boza) & $\mathrm{nd}^{*}$ & - & - \\
\hline Sample 3 (Boza) & $\mathrm{nd}^{*}$ & - & - \\
\hline Sample 4 (Malt Beer) & 196.80 & 2.37 & 1.20 \\
\hline Sample 5 (Malt Beer) & 146.42 & 1.59 & 1.09 \\
\hline $\begin{array}{l}\text { Sample 6 (Vitamin } \\
\text { Fortified Malt Beverage) }\end{array}$ & 36.65 & 0.92 & 2.50 \\
\hline $\begin{array}{l}\text { Sample 7 (Vitamin } \\
\text { Fortified Malt Beverage) }\end{array}$ & 42.96 & 1.67 & 3.88 \\
\hline
\end{tabular}

*nd: not detected.
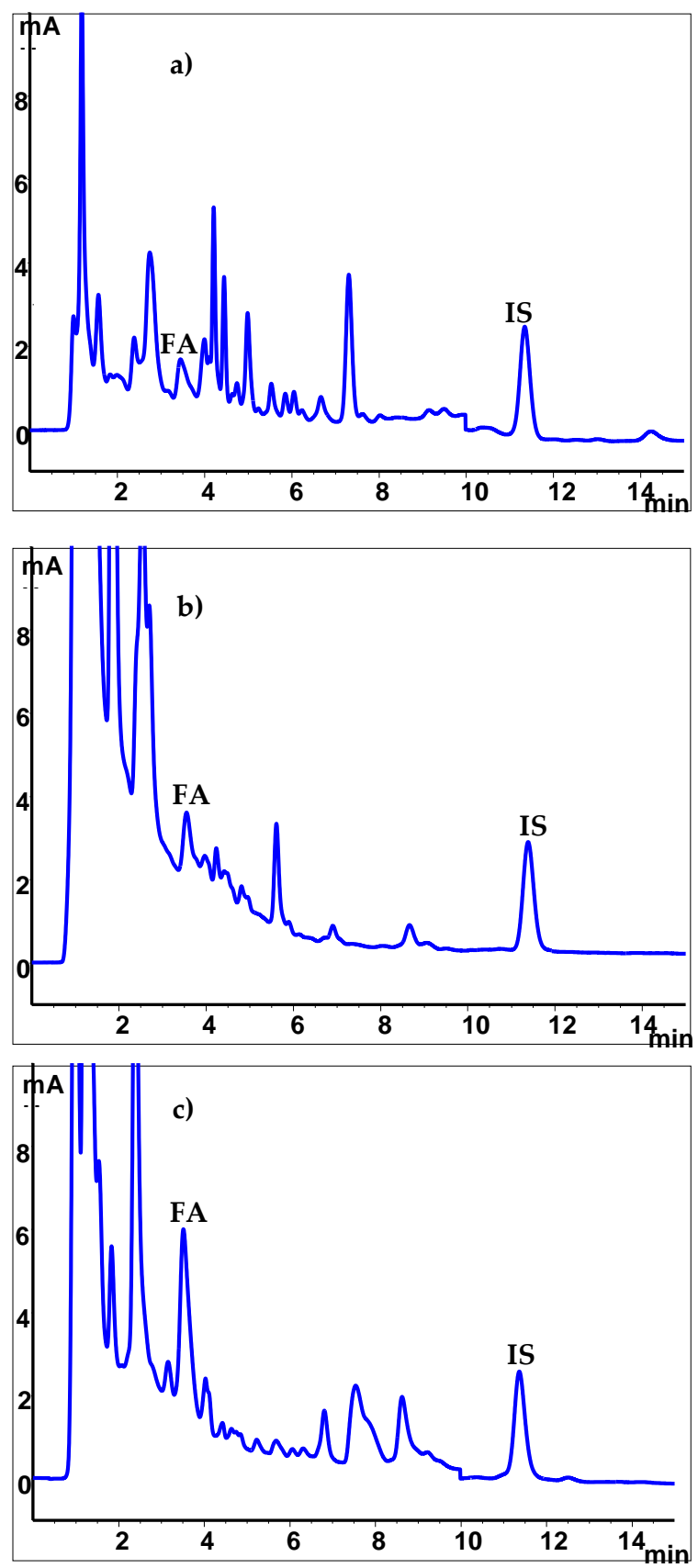

Figure 2. Representative chromatograms obtained from malt-based beverages using the proposed UHPLC method a) Boza, b) Vitamin Fortified Malt Beverage, and c) Malt beer sample.

\section{Conclusion}

An efficient UHPLC method was developed and validated for the determination of FA in certain maltbased beverages in this study. The validated study reveals that this method is precise, accurate and sensitive. In the current study, FA is separated in a relatively short time by the developed UHPLC method. Besides, UHPLC reduces flow rates of the mobile phase when compared with HPLC and shows an important gain in analysis time and solvent consumption. It is the first study which includes the determination of FA in boza sample. A 
comparison of the proposed method with literature was presented in Table 7. Consequently, this work gives a new information about folic acid content in malt-based beverages, which should be favourable for food databases and the developed method is suitable for the routine quantification of FA in food analysis.

Table 7. Comparison of the developed method with literature for FA analysis

\begin{tabular}{|c|c|c|c|c|c|c|}
\hline $\begin{array}{l}\text { Retention } \\
\text { Time for } \\
\text { FA (min) }\end{array}$ & $\begin{array}{c}\text { Preconcentration } \\
\text { method }\end{array}$ & $\begin{array}{c}\text { Determination } \\
\text { method }\end{array}$ & $\begin{array}{c}\text { Linear } \\
\text { Range } \\
\left(\mu g \mathrm{~L}^{-1}\right)\end{array}$ & $\begin{array}{c}\text { LOD } \\
\left(\mu g \mathrm{~L}^{-1}\right)\end{array}$ & Applications & Reference \\
\hline 2.0 & -* & UHPLC-DAD & $600-12000$ & NA & $\begin{array}{c}\text { Pharmaceutic } \\
\text { al } \\
\text { preparations }\end{array}$ & {$[1]$} \\
\hline 22 & -* & $\mathrm{CE}$ & 5297-21187 & 270 & Lentils & {$[3]$} \\
\hline $\begin{array}{c}3.5 \\
\text { (Approx.) }\end{array}$ & $\begin{array}{c}\text { Complexation } \\
\text { with Fe(III) } \\
\text { and CPE } \\
\end{array}$ & HPLC-DAD & $20-1200$ & 6.06 & $\begin{array}{c}\text { Food } \\
\text { samples }\end{array}$ & [21] \\
\hline 2.8 & - & UHPLC-MS-MS & $0.01-0.500$ & 0.05 & Serum & [23] \\
\hline- & UAE & $\begin{array}{c}\text { UV } \\
\text { spectrophotometry }\end{array}$ & $0.6-180$ & 0.19 & $\begin{array}{l}\text { Foods and } \\
\text { drugs }\end{array}$ & [42] \\
\hline $\begin{array}{c}11 \\
\text { (Approx.) }\end{array}$ & C18 SPE & HPLC-DAD & $500-20000$ & 100 & Tarhana & [43] \\
\hline 15 & $\begin{array}{l}\text { Trienzyme } \\
\text { extraction } \\
\text { procedure }\end{array}$ & $\begin{array}{l}\text { HPLC-coulometric } \\
\text { electrochemical } \\
\text { detection }\end{array}$ & $50-2500$ & 1.3 & $\begin{array}{c}\text { Fortified fruit } \\
\text { juices and } \\
\text { cereal } \\
\text { products }\end{array}$ & [44] \\
\hline 3.6 & C18 SPE & UHPLC-UV & 20.13-2004 & 6.66 & $\begin{array}{l}\text { Malt-based } \\
\text { beverages } \\
\text { (boza, beer, } \\
\text { malt drinks) }\end{array}$ & This Study \\
\hline
\end{tabular}

NA Not available, CE Capillary electrophoresis, CPE cloud point extraction, UAE ultrasonic-assisted extraction, SPE solid-phase extraction, * the method includes sample preparation and purification procedures which are including dissolution or protein precipitation.

\section{References}

1. Deconinck, E, Crevits, S, Baten, P, Courselle, P, De Beer, J, A validated ultra high pressure liquid chromatographic method for qualification and quantification of folic acid in pharmaceutical preparations, Journal of Pharmaceutical and Biomedical Analysis, 2011, 54, 995-1000.

2. Breithaupt, D.E, Determination of folic acid by ion-pair RP-HPLC in vitamin-fortified fruit juices after solid-phase extraction, Food Chemistry, 2001, 74, 521-525.

3. Uysal, Ü.D, Oncu, E.M, Tuncel, M, Determination of folic acid by capillary electrophoresis in various cultivated variety of lentils, Chromatographia, 2010, 71, 653-658.

4. Tomiuk, S, Liu, Y, Green, T.J, King, M.J, Finglas, P.M, Kitts, D.D, Studies on the retention of microencapsulated L-5methyltetrahydrofolic acid in baked bread using skim milk powder, Food Chemistry, 2012, 133, 249-255.

5. Hau Fung Cheung, R, Hughes, J.G, Marriott, P.J, Small, D.M, Analytical methods investigation of folic acid stability in fortified instant Asian noodles by use of capillary electrophoresis, Food Chemistry, 2009, 112, 507-514.

6. Lucock, M, Folic acid: Nutritional biochemistry, molecular biology, and role in disease processes, Molecular Genetics and Metabolism, 2000, 71(1/2), 121-138.

7. Francis, F.J, Encyclopedia of Food Science and Technology; John Wiley \& Sons: New York, U.S.A., 1999.
8. Fajardo, V, Alonso-Aperte, E, Varela-Moreiras, G, Lack of data on folate in convenience foods: Should ready-to-eat products be considered relevant for folate intake? The European challenge, Journal of Food Composition and Analysis, 2012, 28, 155-163.

9. Hau Fung Cheung, R, Morrison, P.D, Small, D.M, Marriott, P.J, Investigation of folic acid stability in fortified instant noodles by use of capillary electrophoresis and reversed-phase high performance liquid chromatography, Journal of Chromatography A, 2008, 1213, 93-99.

10. Centers for Disease Control, Recommendations for the use of folic acid to reduce the number of cases of spina bifida and other neural defects. 1992, MMWR: 41(No. RR14):1.

11. Pantuckova, P, Krivankova, L, Analysis of 5methyltetrahydrofolate in human blood, serum and urine by on-line coupling of capillary isotachophoresis and zone electrophoresis, Electrophoresis, 2010, 31, 3391-3399.

12. Opladen, T, Ramaekers, V.T, Heimann, G, Blau, N, Analysis of 5methyltetrahydrofolate in serum of healthy children, Molecular Genetics and Metabolism, 2006, 87, 61-65.

13. Zhao, S, Yuan, H, Xie, C, Xiao, D, Determination of folic acid by capillary electrophoresis with chemiluminescence detection, Journal of Chromatography A, 2006, 1107, 290-293.

14. Edelmann, M, Kariluoto, S, Nyström, L, Piironen, V, Folate in barley grain and fractions, Journal of Cereal Science, 2013, 58, 37-44. 
15. Arcot, J, Shrestha, A, Folate: methods of analysis, Trends in Food Science\&Technology, 2005, 16, 253-266.

16. Puwastien, $\mathrm{P}$, Pinprapai, $\mathrm{N}$, Judprasong, $\mathrm{K}$, Tamura, $\mathrm{T}$, International inter-laboratory analyses of food folate, Journal of Food Composition and Analysis, 2005, 18, 387-397.

17. Zhang, T, Xue, H, Zhang, B, Zhang, Y, Song, $P$, Tian, X, Xing, Y, Wang, P, Meng, M, Xi, R, Determination of folic acid in milk, milk powder and energy drink by an indirect immunoassay, Journal of the Science of Food and Agriculture, 2012, 92, 2297-2304.

18. Matias, R, Ribeiro, P.R.S, Sarraguça, M.C, Lopes, J.A, A UV spectrophotometric method for the determination of folic acid in pharmaceutical tablets and dissolution tests, Analytical Methods, 2014, 6, 3065-3071.

19. Jastrebova, J, Witthoft, C, Grahn, A, Svensson, U, Jagerstad, M, HPLC determination of folates in raw and processed beetroots, Food Chemistry, 2003, 80, 579-588.

20. Ulusoy, H.İ, Acıdereli, H, Ulusoy, S, Erdoğan, S, Development of a new methodology for determination of vitamin B9 at trace levels by ultrasonic-assisted cloud point extraction prior to HPLC, Food Analytical Methods, 2017, 10, 799-808.

21. Ulusoy, S, Acıdereli, H, Erdoğan, S, Ulusoy, H.I, A new approach to the determination of folic acid at trace levels: using a Fe(III)-folic acid complex to amplify analytical signal, RSC Advances, 2016, 6, 40115-40122.

22. Pawlosky, R.J, Flanagan, V.P, Doherty, R.F, A mass spectrometric validated high-performance liquid chromatography procedure for the determination of folates in foods, Journal of Agricultural and Food Chemistry, 2003, 51, 3726-3730.

23. Wang, $X$, Zhang, T, Zhao, $X$, Guan, Z, Wang, Z, Zhua, Z, Xie, Q, Wang, J, Niu, B, Quantification of folate metabolites in serum using ultraperformance liquid chromatography tandem mass spectrometry, Journal of Chromatography B, 2014, 962, 9-13.

24. Eitenmiller, R.R, Landen, W.O, Ye, Jr.L, Vitamin Analysis for the Health and Food Sciences; Second Edition CRC Press: Boca Raton, U.S.A., 2007; pp 664.

25. Nováková, L, Solichová, D, Solich, P, Advantages of ultra performance liquid chromatography over high-performance liquid chromatography: comparison of different analytical approaches during analysis of diclofenac gel, Journal of Separation Science, 2006, 29(16), 2433-43.

26. Núnez, O, Gallart-Ayala, H, Martins, C.P.B, Lucci, P, Review New trends in fast liquid chromatography for food and environmental analysis, Journal of Chromatography A, 2012, 1228, 298-323.

27. Yang, G.-L, Yang, L.-W, Li, Y.-X, Cao, H, Zhou, W.-L, Fang, Z.J, Zhou, H.-B, Mo, J.-L, Xiao, S.-X, Lin, H.-R, Applications of ultraperformance liquid chromatography to traditional chinese medicines, Journal of Chromatographic Science, 2010, 48, 18-21.

28. Klimczak, I, Gliszczynska-Swigło, A, Comparison of UPLC and HPLC methods for determination of vitamin C, Food Chemistry, 2015, 175, 100-105.
29. AOAC Official Method 944.12. Folic acid (pteroylglutamic acid) in Vitamin Preparations, Microbiological Methods, 1960.

30. AOAC Official Method 992.05. Folic Acid (Pteroylglutamic Acid) in Infant Formula. In: Horwitz, W. (Ed.) Official Methods of Analysis. 17. edn. Gaithersburg, MD.: AOAC International; 2, 2000, pp 50.02450.026 .

31. AOAC Official Method 2004.05. Total Folates in Cerals and Cereal foods. In. 10. edn. Gaithersburg, MD, 2004.

32. European Committee for Standardization (CEN), EN 14131:2003. Foodstuffs. Determination of Folate by Microbiological Assay, 2003.

33. Strandler, H.S, Determination of Folate for Food Composition Data, Licentiate Thesis, Swedish University of Agricultural Sciences, Uppsala, 2012.

34. Preedy, V.R, Beer in Health and Disease Prevention; Elsevier/Academic Press: Boston, U.S.A., 2009.

35. Yegin, S, Üren, A, Biogenic amine content of boza: A traditional cereal-based, fermented Turkish beverage, Food Chemistry, 2008, 111, 983-987.

36. Genc, M, Zorba, M, Ova, G, Determination of rheological properties of boza by using physical and sensory analysis, Journal of Food Engineering, 2002, 52, 95-98.

37. De Quirós, A.R.-B, de Ron, C.C, López-Hernández, J, Lage-Yusty, M.A, Determination of folates in seaweeds by high-performance liquid chromatography, Journal of Chromatography A, 2004, 1032, 135-139.

38. Uysal, Ü.D, Öncü, E.M, Berikten, D, Yilmaz, N, Tuncel, N.B, Kivanc, M, Tuncel, M, Time and temperature dependent microbiological and mycotoxin (ochratoxin-A) levels in boza, International Journal of Food Microbiology, 2009, 130, 43-48.

39. Prieto, S.P, Grande, B.C, Falcon, S.G, Gandara, J.S, Screening for folic acid content in vitamin-fortified beverages, Food Control, 2006, 17, 900-904.

40. Validation of Analytical Procedures: Methodology, The International Conference on Harmonization (ICH), Topic Q2B, CPMP/ICH/281/95, 1996.

41. Bassett, M.N, Sammán, N.C, Folate content and retention in selected raw and processed foods, Archivos Latinoamericanos de Nutrición, 2010, 60(3), 298-305.

42. Gürkan, R, Altunay, N, A simple and efficient ultrasonic-assisted extraction procedure combined with UV-Vis spectrophotometry for the pre-concentration and determination of folic acid (vitamin B9) in various sample matrices, Food Additives\&Contaminants Part A, 2016, 33(7), 1127-1138.

43. Ekinci, R, Kadakal, Ç, Determination of seven water-soluble vitamins in tarhana, A traditional turkish cereal food, by highperformance liquid chromatography, Acta Chromatographica, 2005, 15, 289-297.

44. Lebiedzinska, A, Dabrowska, M, Szefer, P, Marszall, M, Highperformance liquid chromatography method for the determination of folic acid in fortified food products, Toxicology Mechanisms and Methods, 2008, 18, 463-467. 